\title{
POLYCLONAL B-CELL ACTIVATION IN HUMAN MALARIA: RELEVANCE TO THE DEVELOPMENT OF ANTI-SPOROZOITE SPECIFIC IMMUNE RESPONSE AND OF IMMUNOPATHOLOGY IN INDIVIDUALS FROM ENDEMIC AREAS (RONDONIA STATE - BRAZIL)
}

Claudio DANIEL-RIBFIRO, Dalma Maria BANIC. Joseli de OI.IVEIRA-FERREIRA, Ishiraf ISSA-AHMED

\& Antonio TEVA.

KEY WORDS: Malaria; Polyclonal B cell activation: Anaemia; Immunoglobulin sensitization of erythrocytes: Anti-sporozoite antibodies: Immunoradionetric assay; Pla que forming cell: Man.

\section{RELEVANCE OF POLYCLONAL B-CELL ACTIVATION (PBA) TO THE DEVELOPMENT OF THE MALARIA ANAEMIA.}

Malaria is caused by an obligate intracellu lar parasite that infect and destroy red blood cells (RBC) during its cycle in the vertebrate host. The infection is therefore accompained by a variable degree of anaemia that however does not correlate with the degree of parasitaenia in the infected host, fact that suggest the partici pation of immunological factors in the genesis of the malaria associated anaemia.

Besides to the mechanical rupture and an anti plasmodial antibody (Ab) dependent lysis of infected $\mathrm{RBC}$ (for review see reference ${ }^{12}$ ) and a mild degree of bone marrow depression ${ }^{13}$, several immune mechanisms could operate in the pro. duction of the anaernia ${ }^{14}$. One of the evoked me chanisms is the formation of anti-erythrocyte Au to-Abs that could appear as a result of either cross-reactions between parasites and RBC or polyclonal activation of autoreactive clones of B-lymphocytes specific to RBC antigens ${ }^{8}$.

Indeed it is now clear that polyclonal B-cell activation or activators can lead to Auto-Ab pro. duction $^{3}$ and that Plasmodia are endowed with
PBA properties ${ }^{1.11}$. Moreover PBA can incuce the formation of immune complexes that could adhere to the RBC membrane.

In order to investigate the role of $\mathrm{PBA}$ and of RBC sensitization by immunoglobulins (IgG and $\operatorname{Ig} \mathbf{M}$ ) and complement in the malaria indu ced anaemia we studied 138 malaria infected (MI) and 49 non infected (NMI) individuals for the: a) degree of PBA by a reverse haemolytical plaque assay able at detecting Ig synthesis of any specificity; b) the degree of $\mathrm{RBC}$ sensitiza tion by a sensitive immunoradiometric assay employing class specific anti immunoglobulins and lodinated protein $\mathrm{A}$ ard $\mathrm{C}$ ) the anaemia by classical haematological procedures. Patients were seen at the out patient clinics of SUCAM or hospitalized in the hospital unit of the Fundação SESP both in the town of Ariquemes ( $R$ ondonia-State). Control individuals were assymptomatic local inhabitants without history of pre. vious malaria. This part of the work has been published elsewhere ${ }^{5}$, in this paper we will only summarize the main results and conclusions of this study.

Polyclonal $B$-cell activation, as reflected by an increase in the numbers of IgG and IgM se creting cells (IgSC) in the peripheral blood, was

Department of Immunology WHO Collaborating Center for Resedreh and Traning in Immunohogy of Parastie Doseasest Inst ituto Oswaldo Cruz -- Fundaça Oswaldo Cruz. Caixa Postal 926. CEP 20001 Rio de Janeiro Brazil. 
DANIEL RIBEIRO, C, BANIC, D. M; OLIVEIRA FERRFIRA, J de ISSA AHMFD. I. \& TEVA. A. -- PUIYClOnal B Cell activation in human malaria: relevance to the development of anti-sporozoite specitic immune response and of immunopathology in individuals from endemic areas (Rondonia State Brazil). Rev. Inst. Med. trop. Sao Paulo, 30 (6): $415-418.1988$.

observed in both $\mathbf{P}$. vivax and $\mathbf{P}$. falciparum MI but not in NMI. Although the numbers of IgASC were not above the normal figures a positive and significant relationship was observed between these numbers and those of IgMSC and of IgGSC in both cases of Plasmodial infection. In addition, the degree of PBA was positively related to that of parasitaemia but no relationship could be detected between the former and the number of past attacks of malaria (PAM). In the same way no difference was observed in the number of $\operatorname{IgSC}(\mathrm{G}, \mathrm{A}$ or $\mathrm{M}$ ) between males and females or those above and below thirty (the mean age of the studied population).

The percentages of IgG (but not of IgM or C3d) sensitized RBC were significantly higher in MI than in NMI and a positive relationship was observed between the numbers of IgM-RBC and those of IgG-RBC and between those of IgM and of C3d-RBC. No relationship was however observed between the amount of sensitized RBC and the parasitaemia

Malarious individuals presented low haematocrite and haemoglobin values, however no relationship could be observed between these values and the parasitaemia. In order to study the role of PBA in the RBC sensitization and the malaria associated anaemia we study the relationship between: a) the degrees of $P B A$ and of $R B C$ sensitization; b) the levels of PBA and of anae. mia and $c$ ) the degrees of RBC sensitization and that of anaemia. No relationship could be observed between the degree of activation of Ig secreting cells of a given class and the sensitization of RBC by the same class of Ig showing that the PBA does not seem to be directly involved in the RBC sensitization by immunoglobulin. In $P$. vivax MI a significant and positive relationship was observed between the amount of IgG sensitized RBC and the degree of anaemia and although such a relationship could not be observed in P. falciparum MI the haematocrite values were significantly lower in P. falciparum MI with high levels than in those with low levels of IgGRBC.

Taken together these data suggest that although the PBA phenomenon can be excluded as the sole cause of $I g$ sensitization of $R B C$, and of anaemia the IgG sensitization of RBC could be involved in pathogenesis of the malaria asso ciated anaemia. Whether these Immunoglobu lins are indeed anti-erythrocyte auto-antibodies or are in fact $A b s$ complexed to malarial antigens passively adsorbed to the $\mathrm{RBC}$ membrane is a matter of study in our laboratory but our prelimi nary results seems to indicate that the second hypothesis is more likely.

\section{CNA PBA INTERFERE, WITH THE DEVELOPMENT OF ANTI-SPOROZOITE IMMUNITY?}

It has been known for a long time that the administration of PBA such as the lipopolysac charide of $\mathbf{E}$. coli to mice, situation associated to a polyclonal $\mathrm{B}$ cell activation status, before the injection of a given antigen can suppress the immune response to this antigen in addition, diseases caused by parasites endowed with PBA properties such as American or African trypano somiasis, (for review see 4 ) are also associated to an immunosuppression to several antigens.

Therefore it should be of interest to evaluate whether or not the malaria associated PBA phe nomenon could represent a handicap to the de velopment of an effective anti-sporozoite immu nity.

In order to study this point 95 malaria infec ted and 21 non infected individuals from the town of Ariquemes (Rondonia-State) in the northwest of Brazil were assessed for the percentage of IgG and IgM secreting cells in the peripheral blood and for the level of anti-sporozoite antibodies (by a immunoradiometric assay using the (NANP)3 synthetic peptide that corresponds to the immunodominant epitope of the CS protein of the sporozoite membrane). The results of this study are been published elsewere ${ }^{6}$, but, once more, here we will summarize its main results and conclusions.

A significant and positive relationship was observed between the anti-(NANP)3 Ab levels and the number of past attacks of malaria (PAM) but not between the former and the age or the time of residence of individuals in the region. Individuals with high numbers of IgGSC or IgMSC presented lower levels of anti-(NANP)3 $\mathrm{Ab}$ and conversely those with levels of anti 
DANIEL RIBEIRO.C.; BANIC, D M.; OLIVEIRA FERREIRA, J. de ISSA AHMED. I. \& TEVA. A - Polyclonal B cell activation in human malaria: relevance to the development of anti-sporozoite specific immune response and of immunopathology in individuals from endemic areas (Rondonia State. Brazill. Rev. Inst. Med. trop. Sāo Paulo, $30(6): 415 \cdot 418,1988$

(NANP)3 Ab above the main level calculated by MI showed normal values of IgGSC and of IgMSC as well as of haematocrite and haemo globin.

Three hypothesis were considered to explain this negative relationship between PBA and an ti-(NANP)3 Ab levels. The first postulates that PBA and low responsiveness would be only mar ker for a third unrelated (intrinsic or extrinsic) factor that would determine the ability of B-cells to be activated during malaria infection, the second hypothesis considers that individuals with higher levels of anti-(NANP)3 Ab would be more protected against malaria and consequently mo re protected against the $\mathrm{PBA}$ induced by mala ria. In this regard it should be emphasized that anti-(NANP)3 Ab positive individuals had num bers of IgGSC and of IgMSC as well as haema tocrite and haemoglobin values similar to those re gistered for non infected individuals. Finally the third hypothesis postulates an inverse cause ef fect relationship, i.e. individuals with high de grees of PBA could be less able to elaborate an effective anti-sporozoite immune response. This mechanism is illustrated by the finding ${ }^{2,3}$ that a crude extract of $\mathbf{T}$. cruzi tyrpomastigotes, that mimicked the PBA properties of the infection, could suppress the immune response to the spe cific antigen when injected prior to the Ag injection. One additional evidence to this mechanism is the observation that blood stage induce $\mathbf{P}$. berghei infection a situation known to be asso ciated with $\mathrm{PBA}^{11}$ can suppress the production of anti-sporozoite antibodies in mice vaccinated with irradiated sporozoites ${ }^{10}$.

If the last hypothesis is correct, and since we have recently observed that the malaria asso ciated PBA disappeared in a 10 days period after the treatment was started, chemotherapeutic measures should be considered before any im munoprophylatic campaing are initiated in populations chronically exposed to the risk of malaria infection.

\section{CONCLUSIONS}

The results overviewed here seem to indicate that: a) a polyclonal $\mathrm{B}$-cell activation, re flected by an increase in the number of immuno. globin (IgG and IgM) secreting cells in the peri. pheral blood, exists in malaria infected indivi duals, b) this PBA status does not seem to be involved in the RBC sensitization by Ig or in the malaria associated anaemia but could affect the anti-sporozoite specific immune response and $\mathrm{c}$ ) the RBC sensitization by IgG could participate in the genesis of the malaria anaemia in $\mathbf{P}$. vivax anc even, in a less extent, in $\mathbf{P}$. falciparum infec ted individuals.

\section{ACKNOWLEDGEMENT'S}

We are indebt to Drs. Agostinho Cruz Marques, João Bosco Pereira and Romeu Rodrigues Fialho from SUCAM and Mário Lemos Filho, Or lando Justino de Araújo, Percival da Costa Pinheiro Machado and Sandra Ferraciole from the Fundaça a SESP for all the facilities provided during the work in the field. We also thank $\mathrm{Mr}$. Oseas Borges da Silva Fundação SESP. This study received financial support from the CNPq - Brazil (Polonoroeste proc. n? 700.418/85 -- and PIDE VI proc. n? $401052 / 85$ ) and the UNDP/ World Bank/Bank/WHO Special Programme for Research and Training in Tropical Diseases ID 78618, CDR, DMB, IIA and JOF are recipients of a grant from CNPq.

\section{REFERENCES}

1. BURGER, L.: DANIEL RIBEIRO, C \& BALLET. J. $\boldsymbol{J}$. Kinetics and composition of polyclonal $B$ cell activation during lethal $P$ yoelii $17 \mathrm{XL}$ infection in $\mathrm{CBA} J$ and swiss OF 1 mice. (Submitted).

2. CORSINI. A. C \& COSTA. M. G - Immunosuppression in mice infected with Trypanosoma cruzi (Chagas, lyoyl I. Evidences of polyclonal $B$ cell activation in experimen. tal infections mimicked by an extract prepared from circu lating trypomastigotes. Rev. Inst. Med. trop. S. Paulo 23: $114 \cdot 121,1981 \mathrm{a}$

3. CORSINI. A. C. \& COSTA, M. G. - Immunosuppression in mice infected with Trypanosoma cruzi (Chagas, 1909 ). II Trypomastigote crude extract (TCE) suppress the hu. moral immune response in mice. Rev. Inst. Med. trop. S. Paulo, 23: 122-126, 1981b.

4. DANIEL RIBEIRO, C - L'activation polyclonale des ce llules B.. l'autoimmunite et l'immunosuppression au cours du paludisme. Paris, 1983. TThese Doctorat d'Etat, Universite Paris VII

5. DANIEL RIBEIRO, C.: BANIC. D. M ; ISSA AHMED, I \& GALVÁO CASTRO, B - Polyclonal B-lymphocite ac tivation and sensitization of erythrocytes by $\mathrm{IgG}$ in human malaria: relevance to the development of anaemia 
DANIEL RIBEIRO, C BANIC. D M OLIVEIRA FERREIRA. J de ISSA AHMED. I \& TEVA A - Polvclonal B ceil activation in human malarla: relevarice to the development of anti-sporozoite specific immune response and of immunopathology in individuals from endemic areas (Kondonia State Brazil. Rev. Inst. Med. trop. Saw Pauso. 30 (6): 415418.1988

in a holoendemic ared in northwestern Brazil 1 Ariquemes Rondonia). Mem. Inst. Oswaldo Cruz, 1/Supp. II 169176 1986

6. DANIEL RIBEIRO. C. OLIVEIRA FERREIRA. J : BA NIC. D. M. \& GALVÁ CASTRO. B. - Can malaria asso clated polycional $B$ lymphocyte activation interfere with the development of anti sporozoites specific immunity? Trans, roy. Soc. trop. Med. Hyg. 82, 1988. 1 Hi press

7. DIAMANTSTEIN T. KEPPLER, W BLITSTEIN WILLINGER. E \& BEN EFRAIN S. - SUppression of the primary immune response in vivo to sheep red blood celis by B cell mitogens. Immunology, 30:401 407. 1976

8. HAMMARSTROM, L., SMITH, E.; PRIMI, D. \& MO LLER. G. - Induction of au toantibodies to red blood cells by polyclonal cell aetivators. Nature, 263: 6061.1976

9. LAMBERT, P H : MOREL P A. RENVERSEZ, J C. \& GOLDMAN, M -- Idotypic interactions and immune "um plexes $n$ infections diseases. In. YAMAMURA. V Y \& TADA $T$. ed. -- Progress in immunology. New York. Aca demic Press, 1983. p. 1343
10. ORJIH, A. V \& NUSSENZWEIG, K. S … Plasmodium berghei: suppression of antibody response to sporozoite stage by acute blood stage infection. Clin, exp. Immunol. 38: 18,1979

11. ROSENBERG, Y.J...-Autoimmune and polyclonal B :ell responses during murine malarta. Nature, 274. 170172. 1978

12. SEED, T. M. \& KREIR. J. P. -. In: KREIER. J. P @d - Malaria. vol. 2. Pathology vector studies and culture New York. Academic Press 1980 p. 146

13 WOODRUFF, A. W. ANSUELL. V. E. \& PETTITT L E. -- Cause of anaemia in malaria. Lancet, 110551057. 1979

14 ZUCKERMAN, A. - Recent studies on factors involved in malarial anaemia. Milit. Med., 131 (Suppl. 9) 12011216. 1966

Nota. Este trabalho faz parte do Prujeto Polunoroeste CNPQ e como os demais, nau fol submetido a avaliaçá do Cor po Redatorial da Revista do Institutode Medicina Tropi cal de Sáo Paulo. 